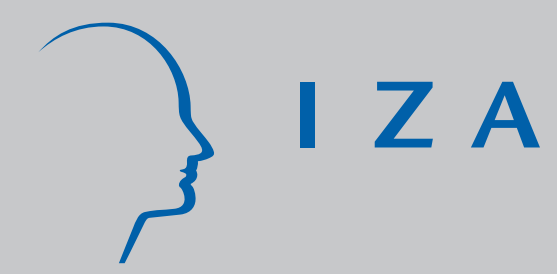

IZA DP No. 301

Economic and Social Perspectives of Immigrant Children in Germany

J oachim R. Frick

Gert G. Wagner

J une 2001 


\title{
Economic and Social Perspectives of Immigrant Children in Germany
}

\author{
Joachim R. Frick \\ German Institute for Economic Research (DIW), Berlin \\ Gert G. Wagner \\ European University Viadrina (Frankfurt/ Oder), \\ German Institute for Economic Research (DIW), Berlin and IZA, Bonn
}

\author{
Discussion Paper No. 301 \\ June 2001
}

\author{
IZA \\ P.O. Box 7240 \\ D-53072 Bonn \\ Germany \\ Tel.: $+49-228-3894-0$ \\ Fax: +49-228-3894-210 \\ Email: iza@iza.org
}

This Discussion Paper is issued within the framework of IZA's research area Mobility and Flexibility of Labor Markets. Any opinions expressed here are those of the author(s) and not those of the institute. Research disseminated by IZA may include views on policy, but the institute itself takes no institutional policy positions.

The Institute for the Study of Labor (IZA) in Bonn is a local and virtual international research center and a place of communication between science, politics and business. IZA is an independent, nonprofit limited liability company (Gesellschaft mit beschränkter Haftung) supported by the Deutsche Post AG. The center is associated with the University of Bonn and offers a stimulating research environment through its research networks, research support, and visitors and doctoral programs. IZA engages in (i) original and internationally competitive research in all fields of labor economics, (ii) development of policy concepts, and (iii) dissemination of research results and concepts to the interested public. The current research program deals with (1) mobility and flexibility of labor markets, (2) internationalization of labor markets and European integration, (3) the welfare state and labor markets, (4) labor markets in transition, (5) the future of work, (6) project evaluation and (7) general labor economics.

IZA Discussion Papers often represent preliminary work and are circulated to encourage discussion. Citation of such a paper should account for its provisional character. 
IZA Discussion Paper No. 301

June 2001

\section{ABSTRACT \\ Economic and Social Perspectives of Immigrant Children in Germany*}

Overall, children in Germany live in households with below average incomes; therefore social policies that address the vulnerable position of Germany's children are necessary. These policies should cover targeted financial transfers as well as improvements in day care provision for children. With respect to selected non-monetary as well as monetary indicators our empirical analyses show significant differences in current living conditions between native born German children and those born to immigrants of German descent and foreign origin persons. Education is a key indicator for future economic and social perspectives. In principle, there is no formal "discrimination" of immigrant children by the German school system. However, low educational attainment levels are still being transferred from one immigrant generation to the next. The net result is that children of immigrants are not able to close the educational gap between themselves and their native German counterparts. The probable long-term consequence will be a large number of poorly qualified persons in the work force, who are much more likely to face severe labor market problems and as such will be a problem for the German economy as a whole for many years to come.

JEL Classification: J13, I30, I21

Keywords: Immigration, children, integration, education

Gert G. Wagner

German Institute for Economic Research (DIW)

Koenigin Luise Strasse 5

14191 Berlin

Germany

Tel: +49-3089789 290

Fax: +49-3089789 109

Email: gwagner@diw.de

* The authors would like to thank Anita I. Drever, UCLA and DIW Berlin, for helpful comments. 
Throughout the last decade the financial situation of children in Germany has been marked by increasing problems: in 1997 the proportion of children living in households receiving welfare payments was about twice as high as their respective share of the entire population. Households with children have lower than average incomes and poverty rates ${ }^{1}$ have increased from about 10 percent to more than 15 percent over the period from the mid 1980s to1996. The central aim of this paper is to compare the effects of this trend on native and non-native children.

Non-native children include children who do not have German citizenship and "ethnic Germans" who migrated from eastern European countries to Germany (Aussiedler). About one half of the immigrants who entered Germany since 1984 are ethnic Germans. Thus, any analysis which compares the living conditions of immigrant children to those of native born German children must take into account the heterogeneity of immigrants in Germany as well as their respective legal status.

In 1995, the share of foreign born persons in Germany was about $9 \%$ of the entire population ${ }^{2}$; in West Germany, where most of the immigrants live, the share of foreign born was about $12 \%$. Because immigrants make up a significant share of the overall population and immigrant women have higher fertility rates than native women, children of non-natives are making up an increasing proportion of all children in Germany. Despite the continuing influx of immigrants to Germany, German society generally does not consider itself to be an "immigrant society" (cf. Heckmann 1999b).

Due to the German citizenship regulations, children born to non-nationals in Germany are considered "immigrant children" regardless of their respective place of birth (abroad or within Germany after their parents immigrated). In contrast to countries like the United States of America, where citizenship is granted to persons born within the country (ius solis), children born in Germany do not automatically receive German citizenship. They receive the nationality of their parents (the right of blood, ius sanguinis). This in turn leads to so-called "second" and even "third generation 
immigrants", the latter being children born to second generation immigrants, who - very often - still hold their original citizenship ${ }^{3}$.

There are two main groups of immigrants in Germany. The first is made up of migrant workers from Mediterranean countries who entered the country in the 1960s and early 1970s (the so-called guestworkers). The second group consists of immigrants from Eastern Europe who arrived after the fall of the Berlin wall in October 1989 who are often referred to as "Ethnic Germans" (Aussiedler). Because of the specific German concept of ethnicity and citizenship it is worthwhile to make certain distinctions when speaking of immigrant children: Figure 1 shows our concept of "immigration status" based on the combination of citizenship and country of birth of children and their parents.

Figure $1 \quad$ Immigration Status in Germany

\begin{tabular}{|l|cc|}
\hline \multirow{2}{*}{ Citizenship (child or parents) } & \multicolumn{2}{|c|}{ Place of Birth (child or parents) } \\
\hline German & in Germany & Abroad \\
Non-German & (A) & (B) \\
& $\begin{array}{c}\text { Native Born } \\
\text { German } \\
(\mathrm{C} 1)\end{array}$ & $\begin{array}{c}\text { German Immigrant } \\
\text { (mainly Aussiedler) } \\
\text { (C2) }\end{array}$ \\
& $\begin{array}{c}\text { Native Born Foreigner } \\
\text { "Second and Third Generation" }\end{array}$ & $\begin{array}{l}\text { Foreign Born Foreigner } \\
\text { (classic immigrant case) }\end{array}$ \\
\hline
\end{tabular}

In our analysis we pay special attention to differences in the situation of immigrant and foreign children as compared to those born to native born German parents. Mostly, we will differentiate three groups of children depending on their family roots:

- A: the mainstream of Native Born Germans

- B: German Immigrants (mainly Aussiedler)

- $\mathrm{C} 1+\mathrm{C} 2$ : Foreigners (Foreign Born and Native Born).

As measures of short term living conditions we analyze income position, poverty risk, and some selected indicators concerning household structure, employment, and the housing situation. In addition, we use language proficiency as well as some habitual indicators to shed more light on the process of cultural assimilation into German society. Finally, our major indicator for long run prospects for children is the current educational enrollment of teenagers, which is closely linked to their future development.

The federal government recently introduced some changes in the legislation concerning citizenship and naturalization. For the following empirical analyses these changes are not relevant, since they are based on data up until 
The micro data used for the following analysis comes from the German Socio-economic Panel Study (SOEP). This survey was started in 1984 in West Germany and was extended to the former German Democratic Republic (East Germany) in June 1990, shortly before unification (cf. Wagner et al 1993). Because most of the immigrants who entered Germany after the late 1980s settled down in newly created households which are not covered by the ongoing panel study a new sub-sample was introduced to the SOEP in 1994/95, titled the "immigrant sample" (cf. Burkhauser et al 1997).

For this paper we are exploiting data for the years 1995/96 for East and West Germany which includes the most recent immigrant population ${ }^{5}$. The following descriptive analyses focus on children in unified Germany, however the regression estimates concentrate on West Germany, where most of the children born to immigrants and foreigners reside. ${ }^{6}$

While all adult members of a given household are interviewed personally in the SOEP, information about children up to 16 years of age is gathered by questions asked from the main respondent who is usually the household head which restricts the data available to us on the youth population. The data we do have includes age, gender, and some more detailed information concerning enrollment in preschool, school, or other educational settings. In addition, the SOEP does contain a lot of data on the household a given child resides in as well as its adult members.

Citizenship data in the SOEP is obtained from the "register file" of the panel study, which contains basic demographic information on each household member (i.e. for adults as well as for children). Eventual immigration related data (country of origin, year of immigration, etc.) is not known for children, but for interviewed adults only, since this data is collected in a special biography

1996.

$4 \quad$ As long as immigrants live in institutions (e.g., refugee camps) they are not part of the SOEP target population of private (non-institutionalized) households.

5 In order to get more stable results we pool information over two years. In our regression analyses we control for this by a time-dummy variable; however, we do not calculate robust standard errors. The number of observations for these analyses are 5,648 in West Germany and 2,122 in East Germany for 1995/96.

For extended analyses of selected indicators, also in comparison to the situation a decade ago in 1985/86, cf. Frick and Wagner (2000). 
questionnaire. Due to the above mentioned differentiation of our sample, we need to know immigration related information for the parents, but not necessarily for the child. ${ }^{7}$

\section{Methodological Aspects}

Our empirical analysis begins with descriptive, mostly bivariate, information on the subpopulations of interest. In our second step we estimate regression models for income, poverty status, and school attendance controlling for a variety of influential factors in order to find out if there are any significant immigration or foreigner related differences in the short term living conditions and long term prospects of children in Germany.

In line with our previous description of nationality and legal status factors we will make use of different variables to identify the subgroups of interest.

- First, we use a simple dummy variable indicating if a child lives in an household with immigrants or if the child stems from immigrants as compared to the mainstream population of Native Born Germans.

- A second variable differentiates between Native Born Germans, German Immigrants and Foreigners. In the regression analyses we further differentiate immigrants and foreigners according to their state of assimilation. We compare children in households of ,single” ethnicity (both parents are immigrants or foreigners) with children of ,mixed” ethnicity, where at least one adult (mostly one parent) is native German (cf. Büchel and Frick 2000).

- A third variable distinguishes children of immigrants by the number of years since migration of the parents. Here we look at those who have lived in Germany for up to 5 years, 6 to 10 years, 11 to 20 years, more than 20 years, and finally those who were born in Germany, but still hold a foreign citizenship and as such belong to the immigrant population according to our definition (see figure 1 above). This differentiation is not only relevant as a measure of time spent in Germany, which is a proxy for chances to be better integrated into the host country's society. The measure can also be used to check the position in the business cycle at the point of time when a person immigrated: we assume that there are long term benefits of entering the country during a

Based on some assumptions one also can define immigrant information for children: e.g. if a child is born after its mother immigrated to Germany, we assume the child to be native born. If the birth took place before the mother migrated, the child would be dealt with as an immigrant. Nevertheless, depending on the mother in this example being an immigrant and/or foreigner herself, the child would be sorted into the corresponding category "German immigrant" or "Foreigner". 
boom period, since this enhances the likelihood of success within the labor market. On the other hand, a person immigrating during a trough period might be more likely to experience long term unemployment.

- Finally, a variable differentiates our population of interest according to the country of origin.

Here we look at those coming from Mediterranean EU-countries (mainly Italy, Spain, Portugal, and Greece), Mediterranean Non-EU-countries (Turkey and the former Yugoslavia), Eastern Europe (including former Soviet Union), Western industrialized countries (e.g. USA, Canada) and a rather heterogeneous rest category, which includes asylum seekers and refugees from other parts of the world.

Without a doubt, individual wellbeing depends on monetary as well as non-monetary factors. However we are dealing mainly with disposable household income and poverty status as the major indicators of general wellbeing. We argue that this is justified because of the many connections, direct and indirect, that economic conditions have with well-being.

Household income is derived from annual income measures, which are calculated for the year prior to the interview. We calculate household income two ways: pre-government income and postgovernment income, which is our measure of disposable income. ${ }^{8}$

- Pre-government income is a measure of the previous years market income, which includes income from employment of any kind, private transfers, net returns on assets (income from interests, dividends or rent), and imputed rental value of owner occupied housing.

- Post-government income is pre-government income minus taxes and social security contributions, plus public transfers and pensions of all sources. Public transfers are the sum of all - mostly means tested - transfers received by all household members throughout the previous year.

In order to adjust income for differences in family or household size, we apply a straightforward equivalence scale, following Atkinson, Rainwater, and Smeeding (1995). We calculate an adjusted "equivalent income", $Y_{e q}$, by dividing disposable household income, $Y_{\text {disp }}$, by the adjusted household

These annual income measures are part of the Cross-National Equivalent Data File produced by Cornell University in Ithaca, NY and the DIW in Berlin, cf. Burkhauser, Butrica and Daly 1999. Using the official consumer price index (CPI) all incomes are measured in DM of 1991. Because there are some differences in the price level in East and West Germany we apply a purchasing power parity index to adjust East German incomes (which are in real terms higher than in nominal terms, cf. Krause 1995). 
size, $S^{\varepsilon}$. For the following calculations we use $\varepsilon=0.5$, which gives the square root of household size.

A very important indicator of well being is the poverty status of households and persons. We calculate the so-called headcount ratio, which is the percentage share of population with income below a certain poverty line. In order to show the threshold sensitivity of our results, we use two different poverty head count ratios. More specifically, we define poverty as the share of population with incomes either below $50 \%$ or $60 \%$ of median income of the entire population ${ }^{9}$.

When differentiating the three subgroups of children in our analyses we make use of other socioeconomic information. Our independent variables include parental age and educational status, household type, community size, housing situation, and unemployment experience of all employable household members. Without a doubt unemployment is a very important determinant of income and other living conditions. The SOEP data allows us to check for recent occurrence of unemployment in a child's household (for each adult household member we have this information based on the month of the interview as well as in the course of previous year). In order to provide more than a snapshot of the current employment situation, we construct an "unemployment index" at the household level. Based on monthly employment status information for the previous calendar year, this index calculates "months with unemployment" as a share of "potential months with employment" for all employable, adult members of a given household. The index is zero if a household is not affected by unemployment at all. It is 100 if all adult members were unemployed during the entire time under consideration. The index is not defined, if all adult members are retirees (e.g., not of employable age) or if they were not able to take up employment due to educational activities, pregnancy, etc.

The educational attainment of the parental population in our sample is very heterogeneous. Educational levels achieved in foreign countries are hard to compare with those of the German system. Thus, parental educational status in our analysis is based on the International Standard Classification of Education (ISCED), which provides a measure of the highest educational status achieved by a child's parents. Due to the problems associated with comparing educational degrees received within Germany with those from abroad (cf. e.g. Reitz et al. 1999), we decided to use a

\footnotetext{
9 The term "entire population" describes all persons living in Germany, thus not only children, but also including those aged 17 and over.
} 
three tiered education variable: "without secondary education", "completed secondary education", and "some post-secondary education" instead of a continuous years of education variable.

For our analyses of long term prospects we use information on actual school enrollment in Germany, since all children observed in our survey are currently being educated within this system. We distinguish between the basic level of Hauptschule which ends after nine years of schooling, Realschule which goes up to tenth grade, and Gymnasium which is university preparation.

\section{$4 \quad$ Empirical Results}

Germany's population structure has been heavily influenced by immigrants because of their age composition and their - up to now - higher fertility rates. Table 1 details the composition of the resident population of persons up to 16 years of age in Germany in 1995/96. In re-unified Germany one out of five children in this age group is born outside of Germany or is a non-national; in West Germany this is the case even for one out of four children.

\subsection{Short-term prospects}

Table 2 displays some descriptive statistics for selected objective and subjective indicators. Because of the greater emphasis on traditional social values in communities of foreign origin persons, we find lone parents to be less likely among children of foreigners compared to both other groups. The situation in East Germany is somewhat different to that of West German natives: The overwhelming majority of children lives in families with 1 or 2 children, larger families are rather rare.

More than $50 \%$ of native German children lived in homes owned by their families during the mid 1990s. In contrast, less than $30 \%$ of children of German immigrants and foreigners live in owneroccupied housing. East German children are only slightly more likely than children of foreign-origin persons to live on their own property. Similarly West German children are -on average- much better off in terms of flat size and number of rooms per capita than any other group. Although the housing conditions for foreigners have been steadily improving, about $50 \%$ of the foreign population complains that their flat size is "too small". 
Unemployment is experienced more frequently in foreign origin and ethnic German immigrant households than in West German households with children. Foreign origin and German immigrant households are the least likely to be unaffected by unemployment (Index $=0 \%)$. Foreign origin households are the most heavily impacted by unemployment. The share of children living in a household without unemployment is only two thirds and almost every tenth foreign origin child in this group lives in a household severely affected by unemployment.

The SOEP data provides a wide range of indicators describing the subjective wellbeing of respondents. We use selected information on satisfaction as well as indicators on worries about overall and individual economic development of parents in order to compare immigrants to the autochthonous population. Beyond that we look at some indicators explicitly targeted at immigrants and foreigners living in Germany.

"Not feeling at home in Germany" is an individual perception that is more pronounced among foreigners than among German immigrants (50\% vs. 39\%). However, the fact that approximately $40 \%$ of ethnic Germans do not feel at home in Germany is remarkable. Additionally, in both groups more than every second child lives in a household, where parents experience a feeling of being discriminated against because of origin. In contrast to children in households of immigrants and foreigners, those born to Native born Germans appear to live with parents who are more concerned about overall economic development (about 55\%) than about personal economic development (23\% for West Germans and not surprisingly $41 \%$ in East Germany). Among foreigners and German immigrants the share of those expressing these worries tends to be more equally distributed (35\% among German immigrants, and 40 to $50 \%$ among foreigners ).

Finally, we look at satisfaction of parents. Comparing statistics on present life satisfaction with expectation of satisfaction with life five years into the future, foreigners seem to be rather optimistic (6.6 vs. 7.3) in comparison with all other groups. On the other hand, parents of foreign origin children and those in East Germany are the least satisfied with their standard of living and their financial situation (measured as household income).

The overall sense one gets from income and poverty indicators (Table 3) is that German immigrant and foreign origin children tend to be significantly worse off than German natives in West Germany. Nevertheless we have to state that children in East Germany are very much like nonnative children in West Germany. All of these findings are basically in line with the results on the 
subjective indicators listed above. Although East German incomes are adjusted for purchasing power differences, they are lower than those of the West German mainstream population and they barely match the income of children born to German immigrants and foreigners in West Germany. Looking at the amount of public transfers received we find not only the highest absolute value for East German children, but this group also exhibits the highest dependency rate measured by public transfers as a percent of post-government income. On the other hand, children of foreigners tend to live in households receiving fewer public transfers in absolute terms.

Relative income positions based on post government income are below population average for all children (because households without children are generally better off than households with children). While the position of native German children and those born to foreign origin persons has been fairly stable since the mid 1980s (cf. Frick and Wagner, 2000), there has been a significant reduction in average family income for children of German immigrants. Due to the major influx of new migrants from Eastern Europe the incomes of German immigrant households dropped from $80 \%$ of the average down to less than $70 \%$, which is in line with their higher dependency on public transfers in the mid 1990s.

Given the above mentioned differences in income levels, the poverty rates (based at a poverty threshold of $50 \%$ of median income) for native German children in West and East Germany as well as for German immigrant children are surprisingly similar at about $15 \%$. On the other hand, children born to foreigners experience a much higher poverty rate of around $24 \%$. Due to differences in the income distribution, raising the poverty line to $60 \%$ of median income yields major increases in the poverty rate for German immigrant children (29\%) and foreigners (36\%), however the increases are less significant for Native German children (21\%).

Obviously, whether measured by monetary or non-monetary indicators, children born to German immigrants and foreign origin parents in West-Germany - on average - live under conditions which are less favorable than those for native German children. However, on theoretical and political grounds it is important to know if the difficulties experienced by immigrant children are due to the immigration status per se (for example via discrimination) or due to the social structure of the immigrant population itself, e.g. poor qualification level of immigrant parents ${ }^{10}$. For this purpose, 
we use multivariate regression models which simultaneously control for a set of independent variables. Dependent variables are equivalent post-government income and poverty status.

Table 4 displays the results of regression models on equivalent post government income. ${ }^{11} \mathrm{We}$ control for parental age, highest educational level of parents, regional information, community size and household or family type. In addition we introduce different indicators of immigration status and we also run a model including unemployment experience by all adult household members ${ }^{12}$.

A dummy variable for the second calendar year of the two-year-period under consideration is introduced for control purposes as well. This time effect does not prove to be significant in any of the regression models on income. Thus, from a substantive point of view the pooling procedure is justified, but our levels of significance are likely to be overestimated, since most of the observations show up twice in the regression. Nevertheless, because most of the effects are highly significant this is not a problem.

Before checking explicitly for immigration specific effects, the list of control variables show the following, mostly expected results:

- All other things being equal, children living in the Midwest experience an income loss of about $12 \%$ relative to the reference group of children living in the Southern part of West Germany. The relative income loss for children living in the North is about $14 \%$.

- There is no significant income difference according to community size.

- The younger the parents, the lower the income position of the family. If a child's parents are younger than 25 years, the child can expect to live in a household where the income is $80 \%$ less than in households where the parents are aged 46 and over.

- Children of lone parents live in households with incomes about 70\% lower than children living with both parents and no other siblings.

- As expected, there is a positive and significant correlation between parental education and income. Children whose parents completed some post-secondary education live in households where the income averages $60 \%$ higher than children in the reference group whose parents did not complete secondary education.

\footnotetext{
11

For methodological reasons, we actually use the natural logarithm of income.

12 Due to potential endogeneity problems we do not include unemployment experience in all of our models. On the other hand, given the higher probability of immigrants to be struck by unemployment, it is of interest to see whether the coefficients for immigrants change once we introduce unemployment experience as well.
} 
By simply controlling for immigrant status of any kind (Model I) we find a negative and significant coefficient which supports the hypothesis that the incomes of immigrants are negatively affected by discrimination. However these results may have arisen from non-observed effects of "ability". Immigrant households make about 13 percent less income than other households (after controlling household structure effects using an equivalent scale and through the inclusion of dummy variables for household types!).

Differentiating immigration status according to single nationality and mixed nationality (i.e., one spouse is native German) in German immigrant and foreign origin households(Model II), shows that single nationality, foreign origin households experience significant income losses of about $36 \%$. This is most likely a result of recent high unemployment rates among foreigners. On the other hand, there is a clear positive effect of "mixed" parental couples: This is true for both, children of German immigrants and those born to foreigners, although only the latter is statistically significant.

Breaking down immigrants by area of origin shows immigrants from Western countries differ significantly from all the other immigrants (Model III). The average income of Western immigrant families is well above that of native born Germans. The coefficients for all other groups of immigrants are negative, as expected. The most significant effects are the negative income deviations for families stemming from non EU, Mediterranean, worker-recruiting countries and for families from Eastern Europe (about $28 \%$ and 25\%, respectively). The coefficient for children coming from "other" countries is also negative and significant due to the large number of asylum seekers and refugees in this group.

If a society is successfully integrating immigrants, their economic well-being should improve with duration of stay in the host country. We control for this by brackets of years since parents' migration (Model IV). As expected, children born to newly arrived immigrants (those who have lived in Germany less than five years) get by on a significantly lower income. There is no significant income differential between foreign origin children whose parents have lived in Germany for more than 20 years and those whose parents were born in Germany.

In order to analyze the impact of past economic success in the labor market, which most likely correlates to the living conditions of immigrants, we add information on unemployment experience (Model V). In terms of the adjusted $\mathrm{R}^{2}$, there is a clear improvement in the explanatory power of 
this model from about $30 \%$ to almost $40 \%$. As expected, there is a negative and highly statistically significant effect of increasing unemployment on disposable income. Moreover, this additional information does not really interfere with the results as they appear above. Except for variables that are correlated with unemployment experience, there is no principal change in our results. The only thing to note is that the magnitude of the coefficients for "parental education" and children whose parents most recently entered Germany is somewhat reduced without losing statistical significance.

Table 5 displays the results of logistic regressions on poverty status in 1995/96. For each model we show odds-ratios ${ }^{13}$ instead of coefficient estimates; a measure of statistical significance is given by the Wald-Statistics ${ }^{14}$. Basically, the results are in line with those of the regressions on income; nevertheless, since by definition the analysis of relative poverty concentrates on the lower tail of the income distribution, there are a few notable exceptions. Again, before looking at immigration specific effects, we check the list of control variables.

- All other things being equal, children living in the Midwest or North of West Germany have a higher risk of falling into poverty than those in the South.

- There does not seem to be any significant difference between children living in the countryside and those living in big cities.

- The younger the parents, the higher the poverty risk for the children.

- Children of single parents are about 7 times as likely to be poor than those living with both parents and no other siblings (reference group). In addition, the greater the number of siblings, the greater the poverty risk.

- Parental education is a very important and highly significant predictor of child poverty. In comparison with the reference group of children whose parents did not complete secondary education, children with highly educated parents (with some post-secondary education) have a poverty risk which is more than $80 \%$ lower.

According to the results of Model I, where we employ a single dummy for all non-native German households, children born to German immigrants and foreigners face a probability of being poor which is about $16 \%$ higher than children in the reference group of native born German households. Controlling for our indicator of assimilation in Model II, we find children with single nationality dummy-variable $x$ indicates that a person with $x=1$ has a risk of being poor approximately $10 \%$ higher as the reference group, all other things being equal. Correspondingly, an odds-ratio value of 0.90 is to be interpreted as an approximately $10 \%$ lower poverty risk as compared to the risk in the reference group. 
foreign parents to be mostly exposed to poverty. Children of "single nationality" German immigrants as well as those of "mixed" foreigners seem to have an even smaller risk of falling into poverty even than native born German children, after controlling for the above mentioned socioeconomic structures. This result might be influenced by some preferential treatment of Aussiedler in the mid 1990s in terms of their eligibility for specific public transfers.

The results of Model III are in line with those of the OLS regressions on income: highest chances of being poor can be found among children stemming from European Non-EU countries (mostly Turkey and the former Yugoslavia) as well as from the category "other" which includes asylum seekers and refugees. On the other hand, children in households coming from EU-countries and other Western industrialized countries again appear to have been positively selected, having a poverty risk lower than that of native born German children.

Model IV differentiates children according to the number of years their parents already spent in Germany: not surprising, those who immigrated most recently (1990 through 1995) are in the worst position. On the other hand, children whose parents arrived in Germany 11 to 20 years ago (i.e. between the mid 1970s and the mid 1980s) are exposed to a significantly lower poverty risk which is only about 60 percent of that of native born children.

Finally, Model V controls for the impact of unemployment. ${ }^{15}$ As expected, we find a clear poverty boosting effect when unemployment in the household context is increased. Again, as was the case for the regressions on equivalent income, it is important to note that the addition of the unemployment effect does not change the overall covariate structure, rather it simply reduces their impact by a small fraction.

\subsection{Long-term prospects}

Especially for the long-run prospects of children parental education is very important. Not surprisingly the educational background of foreign born parents is by far worse than the one of German parents (Table 6). More than a third of foreign origin children live with parents who have less than a secondary education. On the other hand, as a result of there being an increasing share of 
"second generation immigrants" among these foreign origin parents, the share of those with some post-secondary education is $29 \%$. It is important to note the rather poor educational background of the recently arrived German immigrants. The parents of children in the group of German immigrants have an educational level which is only slightly better than the one of foreign immigrants: The share of parents with post-secondary education is smallest in this group. However, these quantitative results cannot give sufficient information on the quality and transferability of educational credentials received abroad (cf. Kreyenfeld and Konietzka 2001). As a result of the GDR educational system, East German children have the lowest share of low-educated parents. In line with our expectation, the educational level of immigrant parents - on average - improves with increasing duration of stay in Germany. Those who originate from Mediterranean worker-recruiting countries are least educated (regardless of whether or not they originate from EU countries), while not surprisingly- highest educational credentials can be found among parents coming from western industrialized countries.

Beyond the formal educational background of parents, their "cultural capital" and especially their language proficiency seem to be important for the success of children in school and society. Table 6 also displays information about languages used at home and some other behavioral indicators. It is not surprising that only $38 \%$ of parents of foreign immigrant's children speak predominantly German at home, while about one out of five foreign children lives in a household where the mother tongue is primarily used. However, given their German ancestry, it is rather surprising that only one half of the children born to German immigrants speak mainly German at home. However, these results mirror the remarkably high share of those "not feeling at home in Germany" (see table 2). On the other hand, the number of foreign origin persons with German citizenship speaking mostly their native language is very small. Breaking down the language proficiency by years since immigration shows a very strong effect: Among recent immigrants 39\% stick to their mother tongue, and only one quarter predominantly speaks German at home. This share is about 40 to $45 \%$ among those who have lived in Germany for more than five years and 76\% among children living in households of "second-generation" foreigners. Consequently, the share of those who are still using the language of their antecedents (together with German) is down to one quarter. In line with the results on the distribution of parental education, the breakdown by country of origin shows that the non-German-speaking fraction is the biggest in the group of parents coming from non-EU European countries, mainly Turkey. 
The kind of food and music which is enjoyed at home as well as the language of newspapers which are read provide additional insight into the process of cultural assimilation. Aussiedler tend not to read newspapers and not to listen to music from their home countries, whereas one third still enjoys the home cuisine. This share is about the same in the group of foreigner's children.

Eating and preparing food as is common in the home country is a long-lasting behavior, which does not vary much by the years since immigration. Among all German immigrants' and foreign origin children, it is only the group of households with second-generation foreigners that have primarily German cooking habits: The share of those preparing food from their country of origin (whatever that is, given that they are born in Germany) is as low as $11 \%$. Differentiating by country of origin, we again can state that the households of persons coming from Mediterranean countries (mostly socalled guestworkers) stick most to their traditional habits: more than $50 \%$ of all children within this group predominantly enjoy meals made as in their home country.

Although, there is no legal discrimination of German immigrant or foreign children in the educational system of Germany, this does not necessarily mean that there are not other obstacles to educational success for non-native children. Some of these difficulties might be related to the cultural differences mentioned above and particularly to language deficiencies. . Table 7 gives some insight in the educational enrollment of the subgroup of 13 to 16 year old children, who are most likely to be on their final school track. In other words, the school where they are educated at this age is most likely the type of school from which they will receive their final degree. ${ }^{16}$ The German school system tracks students at three major levels: "Hauptschule" is the lowest level with graduation after 9 years of school, "Realschule" ends after 10 years, and successfully finishing "Gymnasium" (after 13 years) provides a child with the opportunity to enter university (cf. Wagner et al. 1998). Pupils who successfully finish Hauptschule or Realschule usually will be looking for an apprenticeship to go on with vocational training. Without any doubt, on a tight apprenticeshipmarket the odds are against those with a Hauptschule-degree. Thus, it is most interesting to see which type of school a child is attending since this piece of information is a very good indicator for further development and future economic success.

Breaking down pupils by immigrant status, shows that only one out of five children born to foreigners attends Gymnasium, while a third of Natives (in West and East Germany) and a quarter 
of children born to immigrants with German citizenship are attending this type of school. However, in comparison to the situation in the mid 1980s, there are clear signs of improvement when looking at the share of foreigners attending the lowest school level (Hauptschule). This share dropped from $57 \%$ to $39 \%$ in the mid 1990s (cf. Frick and Wagner 2000).

For a multivariate analysis of the determinants of school enrollment of 13 to 16 year old persons we control for the same covariates as in the regressions on income position and poverty status ${ }^{17}$. Table 8 shows the results of logistic regressions on the probability of "Attending Gymnasium" in 1995/96. Not surprisingly, we find a clearly reduced probability of attending this type of school among children with younger parents. On the other hand, children in metropolitan areas show a slightly higher tendency to be enrolled at the Gymnasium level. We also confirm the well-known fact that education levels between different generations of the same household are highly correlated . In comparison to the reference group which includes children whose parents did not complete secondary education, we find an increased likelihood of attending Gymnasium among those kids whose parents' highest educational level is post-secondary education (e.g., a university degree).

More important to our research question is the impact measured by immigration specific variables on school enrollment. At first glance it might be surprising that we do not find a significant effect for the simple immigration dummy (Model I). In other words, it does not seem to be immigration status per se that accounts for the descriptive differences in educational enrollment, but rather other socio-economic effects. Nevertheless, Model II exhibits a significantly higher probability of attending Gymnasium for children of "mixed" parental couples consisting of foreigners and native Germans. Accounting for the country of origin in Model III, children coming from western industrialized countries appear to be in the most advantageous position, in other words: children of native Germans are doing worse.

In contrast to the regression results on poverty risk (Table 5), we do not find a significant effect for children of most recent immigrants, though the direction of this impact is as expected negative. If integration is an ongoing process, one would expect that this situation would improve with duration of stay within the host country. In fact, -other things being equal-children whose parents have 
lived in Germany for 10 to twenty years have an even higher probability of attending Gymnasium than the reference group of native born German children. ${ }^{18}$

\section{Conclusion and Outlook}

Our comparative analyses are based on the different sub-samples of the German Socio-Economic Panel Study (SOEP). With respect to selected non-monetary as well as monetary indicators there are- despite Germany's fairly effective transfer system- significant differences in living conditions between native born German children and those born to immigrants of German descent and foreign origin persons. Overall, we find that children in Germany live in households with below average incomes therefore social policies that address the vulnerable position of Germany's children are necessary. These policies should cover targeted financial transfers as well as improvements in day care provision for children. Access to day care is particularly critical because not only does it make it easier for parents to hold a job, it also provides immigrant children with an educational head start.

There is no formal "discrimination" of immigrant children by the German school system. However low educational attainment levels are still being transferred from one immigrant generation to the next. The net result is that children of immigrants are not able to close the educational gap between themselves and their native German counterparts. The probable long-term consequence will be a large number of poorly qualified persons in the work force, who are much more likely to face severe labor market problems and as such will be a problem for the German economy as a whole for many years to come. In other words, the German educational system, which includes pre-school, school and vocational training, needs to provide equal opportunities to all children regardless of their social background. If necessary, there should be additional incentives for children born to German immigrants and foreign origin persons to overcome language disadvantages.

Until recently, the German government did not view Germany as an immigration country, therefore policies designed to better improve the educational and economic integration of immigrants have received inadequate consideration. In addition, there is an ongoing discussion, both in and outside of academia, regarding the need for an active immigration policy which would recruit immigrants to fill Germany's particular economic needs as well as maintain Germany’s strong tradition of 
providing refuge from political persecution (cf. Zimmermann 1994, Herrmann 1999). Significant increases in immigration are necessary if Germany is to maintain its standard of living despite its rapidly graying population.

However, the Federal Government has recently made significant advances in the area of integration by facilitating the naturalization (Einbürgerung) of long-term aliens and allowing (temporary) dual citizenship for children born in Germany to foreigners. This can be seen as a first, and very important step towards easing immigrants into society by granting them access to all the legal privileges afforded to German citizens. However it should be noted that integration is a two way process and that "integration willingness" on behalf of the immigrants themselves, such as improvement in their knowledge of the German language, is necessary if they want to achieve economic parity with native Germans. Finally, if the immigrant integration process becomes smoother, Germany will be in a better position to welcome immigrants in the future. 


\section{References}

Atkinson, Anthony B., Lee Rainwater, and Timothy M. Smeeding (1995): Income Distribution in OECDCountries: The Evidence from the Luxembourg Income Study. Paris: OECD.

Büchel, Felix and Joachim R. Frick (2000): The Income Portfolio of Immigrants in Germany. IZA Discussion Paper No. 125, Bonn.

Büchel, Felix, Joachim R. Frick, Peter Krause and Gert G. Wagner (2000): The Impact of Poverty on Children's School Attainment. Evidence for West Germany, In: Vleminckx, Koen and Timothy M. Smeeding (eds.) Child Well-being, Child Poverty and Child Policy in Modern Nations, Bristol: The Policy Press, 151-173.

Büchel, Felix, Joachim Frick, and Wolfgang Voges (1997): Der Sozialhilfebezug von Zuwanderern in Westdeutschland. In: Kölner Zeitschrift für Soziologie und Sozialpsychologie, 49 (2), 272-290.

Burkhauser, Richard V., Michaela Kreyenfeld, and Gert G. Wagner (1997): The German Socio-Economic Panel: A Representative Sample of Reunited Germany and its Parts. In: Dunn, Thomas and Johannes Schwarze (eds.): Proceedings of the 1996 Second International Conference of Socio-Economic Panel Study Users. Vierteljahrshefte zur Wirtschaftsforschung, 66(1), 7-16.

Burkhauser, Richard V., Barbara A. Butrica, and Mary C. Daly (1999): 'The PSID-GSOEP Equivalent File: A Product of Cross-National Research", In: Wolfgang Voges (ed.), Dynamic Approaches to Comparative Social Research: Recent Developments and Applications. Aldershot, Great Britain: Ashgate Publishing Ltd., 53-66.

Deutscher Bundestag (1998a): Demographischer Wandel: Zweiter Zwischenbericht der EnqueteKommission "Demographischer Wandel" - Herausforderungen unserer älter werdenden Gesellschaft an den Einzelnen und an die Politik. Bonn.

Deutscher Bundestag (1998b): Zehnter Kinder- und Jugendbericht. Bundestags-Drucksache 13/11368 vom 25.8.1998.

Frick, Joachim R. and Gert G. Wagner (2000), Living Conditions of Immigrant Children in Germany. In: Vleminckx, Koen and Timothy M. Smeeding (Eds.): Child Well-Being, Child Poverty and Child Policy in Modern Nations, Bristol: The Policy Press, 275-298.

Heckmann, Friedrich (1999a): School Education and Labor Market Integration of Second Generation Migrants in Germany. In: europäisches forum für migrationsstudien (efms) Paper Nr. 29, Bamberg.

Heckmann, Friedrich (1999b): Citizenship and Nation in Germany: Old and New Concepts. In: europäisches forum für migrationsstudien (efms) Paper Nr. 32, Bamberg.

Herrmann, Helga (1999): Selektive Migrationspolitik ist unausweichlich, In: Arbeitgeber 12/49, 394-498

Kreyenfeld, Michaela and Dirk Konietzka (2001): The Transferability of Foreign Educational Credentials The Case of Ethnic German Migrants in the German Labor Market. Max Planck Institute for Demographic Research, Rostock: Mimeo.

Krause, Peter (1995): Ostdeutschland fünf Jahre nach der Einheit: Rückgang der Erwerbsbeteiligung scheint gestoppt, Einkommen gleichen sich weiter an, Armut stagniert. In: DIW-Wochenbericht, 62 (50), 863869.

Reitz, Jeffrey, Joachim R. Frick, Tony Calabrese, and Gert G. Wagner (1999): The Institutional Framework of Ethnic Employment Disadvantage: A Comparison of Germany and Canada. In: Journal of Ethnic and Migration Studies, 25 (3), 397-443.

Wagner, Gert G., Richard V. Burkhauser, and Friederike Behringer (1993): The English Language Public Use File of the German Socio-Economic Panel Study. In: Journal of Human Resources, 28 (2), 429-433

Wagner, Gert G., Felix Büchel, John P. Haisken-DeNew, and C. Katharina Spiess (1998): Education as a Keystone of Integration of Immigrants: Determinants of School Attainment of Immigrant Children in West Germany. In: Kurthen, Hermann, Fijalkowski, Jürgen and Wagner, Gert G. (Eds.): Immigration, Citizenship, and the Welfare State in Germany and the United States: immigrant incorporation, Vol. 14 (A) of Industrial Development and Social Fabric Series of JAI Press Inc., Stamford, CT and London, 1535.

Zimmermann, Klaus F. (1994): Immigration Policies in Europe - An Overview. In: Siebert, Horst (ed.) Migration - A Challenge for Europe. Tuebingen: Mohr, 227-258. 
Table 1 Composition of Resident Children ${ }^{1)}$ Population in Germany in 1995/96

\begin{tabular}{|l|r|r|}
\hline & West Germany & Germany \\
\hline Immigrant Status & 76.8 & 80.5 \\
Native Born German & 6.1 & 5.6 \\
German Immigrant & 17.1 & 13.9 \\
Foreigner & 100.0 & 100.0 \\
Total & & \\
\hline
\end{tabular}

${ }^{1)} \mathrm{Up}$ to 16 years of age.

Source: SOEP, authors' calculations. 

in Germany by Immigrant Status, 1995/96

\begin{tabular}{|c|c|c|c|c|c|}
\hline & & West Ge & ermany & & East \\
\hline & $\begin{array}{c}\text { Native } \\
\text { Born } \\
\text { German }\end{array}$ & $\begin{array}{c}\text { German } \\
\text { Immigrant }\end{array}$ & Foreigner & Total & Total \\
\hline Household Structure & & & & & \\
\hline Lone Parent & 9 & 10 & 4 & 9 & 9 \\
\hline Multi-Adult 1 child & 28 & 22 & 23 & 26 & 34 \\
\hline Multi-Adult 2children & 40 & 37 & 42 & 41 & 44 \\
\hline Multi-Adult $3+$ children & 23 & 32 & 31 & 25 & 13 \\
\hline Housing Situation & & & & & \\
\hline Owner occupier (in \%) & 56 & 27 & 30 & 50 & 34 \\
\hline Number of Rooms & & & & & \\
\hline - Rooms per capita & 1.15 & 0.95 & 0.91 & 1.09 & 1.00 \\
\hline $\begin{array}{l}\text { - Less than } 1 \text { room per capita (in \%) } \\
\text { Housing Space }\end{array}$ & 26 & 52 & 51 & 32 & 37 \\
\hline - Square meters per capita & 29 & 23 & 22 & 28 & 23 \\
\hline - Evaluated as being "too small" (in \%) ${ }^{1)}$ & 28 & 28 & 48 & 32 & 38 \\
\hline Unemployment Experience in previous year ${ }^{2)}$ & & & & & \\
\hline No employable person & 2 & (1) & 3 & 2 & 0 \\
\hline Index $=0 \%$ (no unemployment last year) & 79 & 77 & 66 & 77 & 59 \\
\hline Index $=1-50 \%$ & 17 & 14 & 22 & 18 & 32 \\
\hline Index $=50-100 \%$ & 3 & 8 & 9 & 4 & 10 \\
\hline $\begin{array}{l}\text { Subjective Measures of Well-Being } \\
\text { (Parental Information) }\end{array}$ & & & & & \\
\hline "Not feeling at home in Germany" (in \%) & - & 39 & 50 & - & - \\
\hline $\begin{array}{l}\text { "Feeling of being discriminated against because of } \\
\text { cultural origin" (in } \% \text { ) }\end{array}$ & - & 52 & 55 & - & - \\
\hline Parents expressing being worried about ... & & & & & \\
\hline Overall economic development (in \%) & 57 & 35 & 49 & 54 & 55 \\
\hline Individual economic development (in \%) & 23 & 35 & 40 & 26 & 41 \\
\hline Parental satisfaction with ... & & & & & \\
\hline Life today ${ }^{3)}$ & 7.0 & 7.4 & 6.6 & 6.9 & 6.5 \\
\hline Life five years from now ${ }^{3)}$ & 7.2 & 7.4 & 7.3 & 7.2 & 6.6 \\
\hline Health $^{3)}$ & 7.0 & 7.3 & 7.3 & 7.1 & 7.0 \\
\hline Living standard ${ }^{3)}$ & 7.1 & 7.7 & 6.3 & 7.0 & 6.3 \\
\hline Household income ${ }^{3)}$ & 6.3 & 6.2 & 5.7 & 6.2 & 5.4 \\
\hline
\end{tabular}

( ) Values in parentheses: $\mathrm{n}<30$. - 1) Evaluation by head of household. - ${ }^{2)}$ Months in unemployment as a share of months with potential employment of all employable household members during the previous year. - ${ }^{3)}$ Mean value measured on a 11-point scale from 0 (=not at all satisfied) to 10 (=completely satisfied).

Source: SOEP, authors' calculations. 
Table 3 Income and Poverty Measures for Children in Germany by Immigrant Status, 1995/96

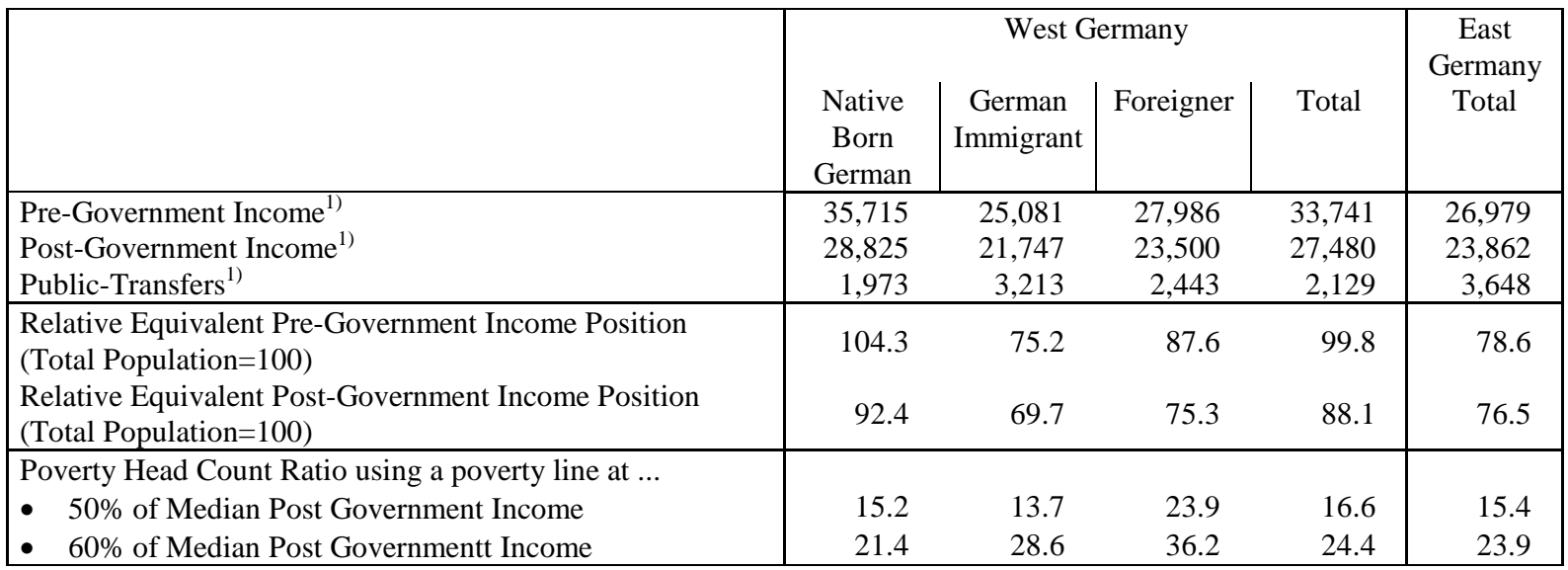

1) In $1991 \mathrm{DM}$.

Source: SOEP, authors' calculations. 
Table $4 \quad$ OLS-Regression Results on Equivalent Income of Children in West Germany, 1995/96 (t-values in parenthesis; $\mathrm{n}=5648$ )

\begin{tabular}{|c|c|c|c|c|c|}
\hline Label & Model I & Model II & Model III & Model IV & Model V \\
\hline Region: & -.121 & -.107 & -.100 & -.115 & -.113 \\
\hline Midwest & $(-7.000)$ & $(-6.239)$ & $(-5.824)$ & $(-6.649)$ & $(-7.011)$ \\
\hline Region: & -.143 & -.140 & -.118 & -.131 & -.132 \\
\hline North & $(-6.900)$ & $(-6.767)$ & $(-5.724)$ & $(-6.299)$ & $(-6.791)$ \\
\hline Metropolitan & .019 & .040 & .038 & .023 & .042 \\
\hline Area & $(.842)$ & $(1.730)$ & $(1.661)$ & $(.991)$ & (1.930) \\
\hline Parental Age & -.806 & -.795 & -.793 & -.782 & -.815 \\
\hline $16-25$ & $(-14.557)$ & $(-14.535)$ & $(-14.448)$ & $(-14.138)$ & $(-15.555)$ \\
\hline Parental Age & -.323 & -.324 & -.318 & -.292 & -.329 \\
\hline $26-35$ & $(-13.925)$ & $(-14.140)$ & $(-13.838)$ & $(-12.422)$ & $(-14.863)$ \\
\hline Parental Age & -.094 & -.111 & -.101 & -.076 & -.081 \\
\hline $36-45$ & $(-4.113)$ & $(-4.930)$ & $(-4.488)$ & $(-3.335)$ & $(-3.802)$ \\
\hline Lone & -.679 & -.691 & -.683 & -.680 & -.526 \\
\hline Parent & $(-22.256)$ & $(-22.904)$ & $(-22.522)$ & $(-22.341)$ & $(-18.100)$ \\
\hline Multi-Adult-HH & -.093 & -.090 & -.088 & -.092 & -.104 \\
\hline with 2 children & $(-4.814)$ & $(-4.732)$ & $(-4.620)$ & $(-4.780)$ & $(-5.764)$ \\
\hline Multi-Adult-HH & -.110 & -.128 & -.136 & -.116 & -.130 \\
\hline with $3+$ children & $(-5.018)$ & $(-5.897)$ & $(-6.203)$ & $(-5.329)$ & $(-6.325)$ \\
\hline Parents with & .282 & .205 & .250 & .275 & .189 \\
\hline Sec. Education & (12.086) & (8.654) & $(10.508)$ & (11.817) & $(8.532)$ \\
\hline Parents with some & .630 & .535 & .579 & .628 & .493 \\
\hline Post-Sec. Education & $(25.925)$ & $(21.331)$ & $(23.147)$ & $(25.905)$ & $(21.186)$ \\
\hline Year & .023 & .021 & .022 & .020 & .014 \\
\hline 1996 & $(1.585)$ & (1.443) & $(1.505)$ & (1.367) & (1.015) \\
\hline $\begin{array}{l}\text { No employable } \\
\text { household member }\end{array}$ & - & - & - & - & $\begin{array}{r}-1.303 \\
(-23.456)\end{array}$ \\
\hline $\begin{array}{l}\text { Unemployment } \\
\text { Index } 1-50 \%\end{array}$ & - & - & - & - & $\begin{array}{r}-.140 \\
(-7.223)\end{array}$ \\
\hline $\begin{array}{l}\text { Unemployment } \\
\text { Index 50-100\% }\end{array}$ & - & - & - & - & $\begin{array}{r}-.735 \\
(-19.496)\end{array}$ \\
\hline $\begin{array}{l}\text { HH with Immigrants } \\
\text { or Foreigners }\end{array}$ & $\begin{array}{r}-.135 \\
(-7.089)\end{array}$ & - & - & - & - \\
\hline $\begin{array}{l}\text { Both Parents are } \\
\text { German Immigrants }\end{array}$ & - & $\begin{array}{r}-.100 \\
(-2.940)\end{array}$ & - & - & - \\
\hline $\begin{array}{l}\text { German Immigrant } \\
\text { and Native German }\end{array}$ & - & $\begin{array}{r}.120 \\
(1.460)\end{array}$ & - & - & - \\
\hline $\begin{array}{l}\text { Both Parents are } \\
\text { Foreigners }\end{array}$ & - & $\begin{array}{r}-.359 \\
(-13.673)\end{array}$ & - & - & - \\
\hline $\begin{array}{l}\text { Foreigner and Native } \\
\text { German }\end{array}$ & - & $\begin{array}{r}.134 \\
(4.141)\end{array}$ & - & - & - \\
\hline $\begin{array}{l}\text { Origin: Medit. } \\
\text { EU-country }\end{array}$ & - & - & $\begin{array}{r}-.023 \\
(-.459)\end{array}$ & - & - \\
\hline $\begin{array}{l}\text { Origin: Medit. } \\
\text { Non-EU country }\end{array}$ & - & - & $\begin{array}{r}-.280 \\
(-8.811)\end{array}$ & - & - \\
\hline $\begin{array}{l}\text { Origin: Eastern } \\
\text { Europe, Former SU }\end{array}$ & - & - & $\begin{array}{r}-.246 \\
(-8.390)\end{array}$ & - & - \\
\hline $\begin{array}{l}\text { Origin: Western } \\
\text { industr. countries }\end{array}$ & - & - & $\begin{array}{r}.289 \\
(6.805)\end{array}$ & - & - \\
\hline $\begin{array}{l}\text { Origin: } \\
\text { other }\end{array}$ & - & - & $\begin{array}{r}-.178 \\
(-3.757)\end{array}$ & - & - \\
\hline $\begin{array}{l}\text { Years since parents } \\
\text { immigrated: } 0-5\end{array}$ & - & - & - & $\begin{array}{r}-.351 \\
(-9.285)\end{array}$ & $\begin{array}{r}-.238 \\
(-6.650)\end{array}$ \\
\hline $\begin{array}{l}\text { Years since parents } \\
\text { immigrated: } 6-10\end{array}$ & - & - & - & $\begin{array}{r}-.139 \\
(-4.291)\end{array}$ & $\begin{array}{r}-.060 \\
(-1.947)\end{array}$ \\
\hline $\begin{array}{l}\text { Years since parents } \\
\text { immigrated: } 11-20\end{array}$ & - & - & - & $\begin{array}{r}-.202 \\
(-5.157)\end{array}$ & $\begin{array}{r}-.205 \\
(-5.591)\end{array}$ \\
\hline $\begin{array}{l}\text { Years since parents } \\
\text { immigrated: }>20\end{array}$ & - & - & - & $\begin{array}{r}.010 \\
(.350)\end{array}$ & $\begin{array}{r}.002 \\
(.086)\end{array}$ \\
\hline Native born & - & - & - & -.060 & -.073 \\
\hline Foreigner & & & & $(-.762)$ & $(-.984)$ \\
\hline (Constant) & 10.057 & 10.138 & 10.083 & 10.038 & 10.211 \\
\hline & (303.006) & $(303.427)$ & $(299.992)$ & $(301.613)$ & $(317.825)$ \\
\hline Adjusted $\mathrm{R}^{2}$ & .291 & .309 & .306 & .298 & .391 \\
\hline
\end{tabular}

Source: SOEP, authors' calculations. 
Table 5 Logistic Regression Results on Poverty Status of Children in West Germany, 1995/96 (Odds-ratios with Wald-Statistic in parenthesis; $\mathrm{n}=5648$ )

\begin{tabular}{|c|c|c|c|c|c|}
\hline Label & Model I & Model II & Model III & Model IV & Model V \\
\hline Region: & 1.324 & 1.366 & 1.339 & 1.329 & 1.416 \\
\hline Midwest & (9.378) & (11.253) & (9.843) & (9.452) & (11.224) \\
\hline Region: & 1.680 & 1.783 & 1.625 & 1.633 & 1.816 \\
\hline North & $(25.620)$ & $(30.766)$ & (21.948) & (22.383) & $(27.485)$ \\
\hline Metropolitan & .834 & .769 & .784 & .818 & .753 \\
\hline Area & (2.227) & $(4.471)$ & (3.880) & $(2.645)$ & (4.123) \\
\hline Parental Age & 9.653 & 9.906 & 9.513 & 9.368 & 14.230 \\
\hline $16-25$ & (98.918) & (98.833) & (96.512) & $(94.095)$ & (112.408) \\
\hline Parental Age & 2.374 & 2.412 & 2.336 & 2.200 & 3.841 \\
\hline $26-35$ & $(45.234)$ & $(46.250)$ & $(43.070)$ & (35.598) & (70.606) \\
\hline Parental Age & 1.164 & 1.254 & 1.159 & 1.081 & 1.310 \\
\hline $36-45$ & (1.265) & (2.768) & (1.169) & $(.321)$ & (2.628) \\
\hline Lone & 7.381 & 7.740 & 7.391 & 7.823 & 5.643 \\
\hline Parent & (238.018) & $(245.633)$ & (233.607) & $(246.926)$ & (140.410) \\
\hline Multi-Adult-HH & 1.018 & 1.014 & 1.020 & 1.031 & 1.074 \\
\hline with 2 children & $(.029)$ & $(.016)$ & $(.034)$ & $(.078)$ & $(.357)$ \\
\hline Multi-Adult-HH & 1.513 & 1.566 & 1.585 & 1.557 & 1.881 \\
\hline with $3+$ children & $(13.416)$ & $(15.494)$ & $(16.352)$ & $(15.062)$ & $(25.187)$ \\
\hline Parents with & .372 & .433 & .388 & .377 & .443 \\
\hline Sec. Education & $(108.302)$ & $(72.201)$ & (91.988) & (102.307) & $(55.972)$ \\
\hline Parents with some & .117 & .140 & .123 & .115 & .178 \\
\hline Post-Sec. Education & $(300.355)$ & $(235.250)$ & $(269.849)$ & $(300.412)$ & $(160.533)$ \\
\hline Year & .757 & .763 & .757 & .779 & .760 \\
\hline 1996 & $(12.985)$ & $(12.140)$ & (12.770) & $(10.300)$ & (10.229) \\
\hline $\begin{array}{l}\text { No employable } \\
\text { household member }\end{array}$ & - & - & - & - & $\begin{array}{r}211.767 \\
(111.650)\end{array}$ \\
\hline $\begin{array}{l}\text { Unemployment } \\
\text { Index } 1-50 \%\end{array}$ & - & - & - & - & $\begin{array}{r}2.205 \\
(63.999)\end{array}$ \\
\hline $\begin{array}{l}\text { Unemployment } \\
\text { Index 50-100 \% }\end{array}$ & - & - & - & - & $\begin{array}{r}29.765 \\
(345.815)\end{array}$ \\
\hline $\begin{array}{l}\text { HH with Immigrants } \\
\text { or Foreigners }\end{array}$ & $\begin{array}{r}1.163 \\
(2.688)\end{array}$ & - & - & - & - \\
\hline $\begin{array}{l}\text { Both Parents are } \\
\text { German Immigrants }\end{array}$ & - & $\begin{array}{r}.582 \\
(9.229)\end{array}$ & - & - & - \\
\hline $\begin{array}{l}\text { German Immigrant } \\
\text { and Native German }\end{array}$ & - & $\begin{array}{r}.365 \\
(2.242)\end{array}$ & - & - & - \\
\hline $\begin{array}{l}\text { Both Parents are } \\
\text { Foreigners }\end{array}$ & - & $\begin{array}{r}1.920 \\
(34.113)\end{array}$ & - & - & - \\
\hline $\begin{array}{l}\text { Foreigner and Native } \\
\text { German }\end{array}$ & - & $\begin{array}{r}.497 \\
(7.359)\end{array}$ & - & - & - \\
\hline $\begin{array}{l}\text { Origin: Medit. } \\
\text { EU-country }\end{array}$ & - & - & $\begin{array}{r}.578 \\
(4.361)\end{array}$ & - & - \\
\hline $\begin{array}{l}\text { Origin: Medit. } \\
\text { Non-EU country }\end{array}$ & - & - & $\begin{array}{r}1.517 \\
(9.520)\end{array}$ & - & - \\
\hline $\begin{array}{l}\text { Origin: Eastern } \\
\text { Europe, Former SU }\end{array}$ & - & - & $\begin{array}{l}1.079 \\
(.311)\end{array}$ & - & - \\
\hline $\begin{array}{l}\text { Origin: Western } \\
\text { industr. Countries }\end{array}$ & - & - & $\begin{array}{r}.083 \\
(10.921)\end{array}$ & - & - \\
\hline $\begin{array}{l}\text { Origin: } \\
\text { other }\end{array}$ & - & - & $\begin{array}{r}2.880 \\
(26.870)\end{array}$ & - & - \\
\hline $\begin{array}{l}\text { Years since parents } \\
\text { Immigrated: } 0-5\end{array}$ & - & - & - & $\begin{array}{r}2.939 \\
(49.364)\end{array}$ & $\begin{array}{r}1.958 \\
(15.505)\end{array}$ \\
\hline $\begin{array}{l}\text { Years since parents } \\
\text { Immigrated: } 6-10\end{array}$ & - & - & - & $\begin{array}{r}.955 \\
(.094)\end{array}$ & $\begin{array}{r}.635 \\
(6.014)\end{array}$ \\
\hline $\begin{array}{l}\text { Years since parents } \\
\text { Immigrated: } 11-20\end{array}$ & - & - & - & $\begin{array}{r}.654 \\
(4.543)\end{array}$ & $\begin{array}{r}.600 \\
(5.710)\end{array}$ \\
\hline $\begin{array}{l}\text { Years since parents } \\
\text { Immigrated: > }\end{array}$ & - & - & - & $\begin{array}{r}.924 \\
(.246)\end{array}$ & $\begin{array}{r}.949 \\
(.087)\end{array}$ \\
\hline $\begin{array}{l}\text { Native born } \\
\text { Foreigner }\end{array}$ & - & - & - & $\begin{array}{r}.730 \\
(.518)\end{array}$ & $\begin{array}{r}.813 \\
(.223)\end{array}$ \\
\hline $\begin{array}{l}\text { Initial -2log: } 5659.34 \\
\text { Model Improvement }\end{array}$ & 1166.23 & 1229.15 & 1232.78 & 1221.01 & 1906.02 \\
\hline
\end{tabular}

Source: SOEP, authors' calculations. 


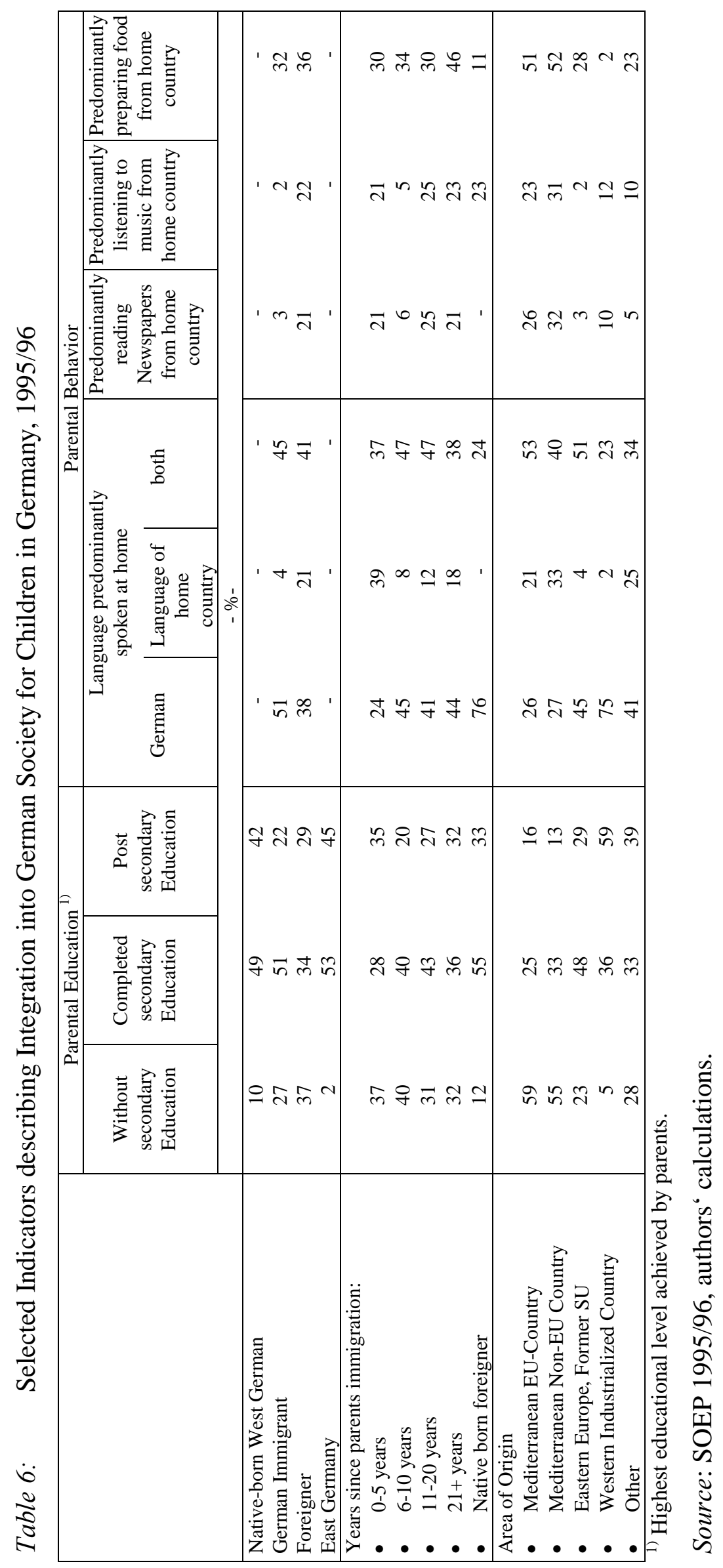


Table $7 \quad$ Educational Enrollment of 13-16 year old Children in Germany in $1995 / 96$ by Immigrant Status

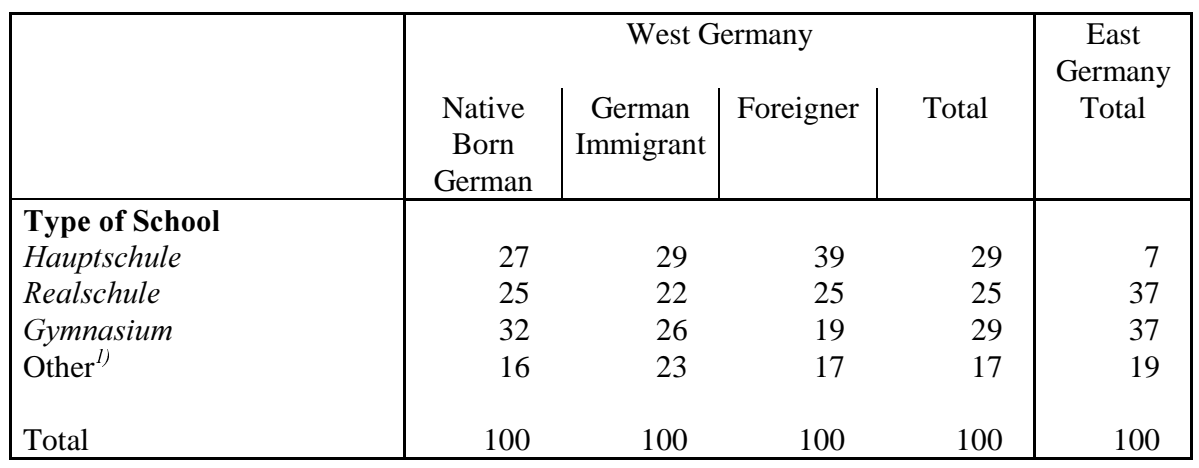

1) This category includes Waldorfschule, Gesamtschule, special schools for the disabled, as well as vocational training.

Source: SOEP, authors' calculations. 
Table 8 Logistic Regression Results on the Probability of "Attending Gymnasium" of 13 to 16 Years old Children in West Germany, 1995/96

(Odds-ratios with Wald-Statistic in parenthesis; $\mathrm{n}=843$ )

\begin{tabular}{|c|c|c|c|c|c|}
\hline Label & Model I & Model II & Model III & Model IV & Model V \\
\hline Region: & 1.290 & 1.377 & 1.341 & 1.306 & 1.329 \\
\hline Midwest & (1.679) & (2.560) & (2.164) & (1.804) & (2.027) \\
\hline Region: & .725 & .782 & .756 & .745 & .766 \\
\hline North & (1.803) & (1.016) & (1.337) & $(1.455)$ & $(1.178)$ \\
\hline Metropolitan & 1.555 & 1.610 & 1.634 & 1.610 & 1.625 \\
\hline Area & $(2.516)$ & $(2.806)$ & (2.998) & (2.837) & (2.919) \\
\hline Parental Age & .193 & .179 & .177 & .211 & .220 \\
\hline $16-35$ & $(17.021)$ & $(18.245)$ & (17.893) & (15.106) & (14.135) \\
\hline Parental Age & .610 & .605 & .615 & .640 & .637 \\
\hline $36-45$ & (7.335) & $(7.512)$ & (6.990) & $(5.735)$ & $(5.841)$ \\
\hline Lone & 1.948 & 2.185 & 1.980 & 1.530 & 1.488 \\
\hline Parent & $(4.062)$ & (5.364) & $(4.156)$ & $(1.442)$ & (1.239) \\
\hline Multi-Adult-HH with & .919 & .953 & .905 & .944 & .926 \\
\hline 2 children & $(.170)$ & $(.054)$ & $(.236)$ & $(.080)$ & $(.140)$ \\
\hline Multi-Adult-HH with & 1.061 & 1.032 & .977 & 1.074 & 1.037 \\
\hline $3+$ children & $(.053)$ & $(.015)$ & $(.007)$ & $(.077)$ & $(.019)$ \\
\hline Parents with Sec. & 4.120 & 3.440 & 3.558 & 3.975 & 3.780 \\
\hline Education & (16.220) & (11.192) & (11.804) & (14.966) & (13.616) \\
\hline Parents with some & 17.526 & 14.635 & 15.210 & 16.861 & 15.228 \\
\hline Post-Sec. Education & $(64.910)$ & $(51.409)$ & $(53.637)$ & $(61.224)$ & $(54.350)$ \\
\hline Year & .783 & .817 & .773 & .740 & .741 \\
\hline 1996 & (1.266) & $(.846)$ & (1.353) & (1.814) & (1.777) \\
\hline $\begin{array}{l}\text { No employable } \\
\text { household member }\end{array}$ & - & - & - & - & $\begin{array}{r}.758 \\
(.112)\end{array}$ \\
\hline $\begin{array}{l}\text { Unemployment } \\
\text { Index 1-50\% }\end{array}$ & - & - & - & - & $\begin{array}{r}.701 \\
(1.684)\end{array}$ \\
\hline $\begin{array}{l}\text { Unemployment } \\
\text { Index } 50-100 \%\end{array}$ & - & - & - & - & $\begin{array}{r}.635 \\
(.594)\end{array}$ \\
\hline $\begin{array}{l}\text { HH with Immigrants } \\
\text { or Foreigners }\end{array}$ & $\begin{array}{l}1.073 \\
(.096)\end{array}$ & - & - & - & - \\
\hline $\begin{array}{l}\text { Both Parents are } \\
\text { German Immigrants }\end{array}$ & - & $\begin{array}{r}.637 \\
(1.435)\end{array}$ & - & - & - \\
\hline $\begin{array}{l}\text { German Immigrant } \\
\text { and Native German }\end{array}$ & - & $\begin{array}{r}2.960 \\
(2.295)\end{array}$ & - & - & - \\
\hline $\begin{array}{l}\text { Both Parents are } \\
\text { Foreigners }\end{array}$ & - & $\begin{array}{r}.756 \\
(.545)\end{array}$ & - & - & - \\
\hline $\begin{array}{l}\text { Foreigner and Native } \\
\text { German }\end{array}$ & - & $\begin{array}{r}2.053 \\
(2.986)\end{array}$ & - & - & - \\
\hline $\begin{array}{l}\text { Origin: Medit. } \\
\text { EU-country }\end{array}$ & - & - & $\begin{array}{r}.739 \\
(.163)\end{array}$ & - & - \\
\hline $\begin{array}{l}\text { Origin: Medit. } \\
\text { Non-EU country }\end{array}$ & - & - & $\begin{array}{r}.662 \\
(.730)\end{array}$ & - & - \\
\hline $\begin{array}{l}\text { Origin: Eastern } \\
\text { Europe, Former SU }\end{array}$ & - & - & $\begin{array}{r}.837 \\
(.321)\end{array}$ & - & - \\
\hline $\begin{array}{l}\text { Origin: Western } \\
\text { industr. countries }\end{array}$ & - & - & $\begin{array}{r}3.351 \\
(3.883)\end{array}$ & - & - \\
\hline $\begin{array}{l}\text { Origin: } \\
\text { other }\end{array}$ & - & - & $\begin{array}{r}2.403 \\
(2.806)\end{array}$ & - & - \\
\hline $\begin{array}{l}\text { Years since parents } \\
\text { immigrated: } 0-5\end{array}$ & - & - & - & $\begin{array}{r}.382 \\
(2.565)\end{array}$ & $\begin{array}{r}.390 \\
(2.410)\end{array}$ \\
\hline $\begin{array}{l}\text { Years since parents } \\
\text { immigrated: } 6-10\end{array}$ & - & - & - & $\begin{array}{r}.615 \\
(.863)\end{array}$ & $\begin{array}{r}.630 \\
(.769)\end{array}$ \\
\hline $\begin{array}{l}\text { Years since parents } \\
\text { immigrated: } 11-20\end{array}$ & - & - & - & $\begin{array}{r}3.678 \\
(7.211)\end{array}$ & $\begin{array}{r}3.640 \\
(6.952)\end{array}$ \\
\hline $\begin{array}{l}\text { Years since parents } \\
\text { immigrated: }>20\end{array}$ & - & - & - & $\begin{array}{l}1.049 \\
(.024) \\
\end{array}$ & $\begin{array}{l}1.056 \\
(.030)\end{array}$ \\
\hline $\begin{array}{l}\text { Initial -2log:1006.04 } \\
\text { Model Improvement }\end{array}$ & 177.01 & 184.40 & 184.94 & 188.75 & 191.02 \\
\hline
\end{tabular}

Source: SOEP, authors' calculations. 


\section{IZA Discussion Papers}

\begin{tabular}{|c|c|c|c|c|}
\hline No & Author(s) & Titel & Area & Date \\
\hline 221 & C. Grund & Wages as Risk Compensation in Germany & 5 & $12 / 00$ \\
\hline 222 & W.P.M. Vijverberg & Betit: A Family That Nests Probit and Logit & 7 & $12 / 00$ \\
\hline 223 & $\begin{array}{l}\text { M. Rosholm } \\
\text { M. Svarer }\end{array}$ & $\begin{array}{l}\text { Wages, Training, and Job Turnover in a Search- } \\
\text { Matching Model }\end{array}$ & 1 & $12 / 00$ \\
\hline 224 & J. Schwarze & $\begin{array}{l}\text { Using Panel Data on Income Satisfaction to } \\
\text { Estimate the Equivalence Scale Elasticity }\end{array}$ & 3 & $12 / 00$ \\
\hline 225 & $\begin{array}{l}\text { L. Modesto } \\
\text { J. P. Thomas }\end{array}$ & $\begin{array}{l}\text { An Analysis of Labour Adjustment Costs in } \\
\text { Unionized Economies }\end{array}$ & 1 & $12 / 00$ \\
\hline 226 & P. A. Puhani & $\begin{array}{l}\text { On the Identification of Relative Wage Rigidity } \\
\text { Dynamics: A Proposal for a Methodology on } \\
\text { Cross-Section Data and Empirical Evidence for } \\
\text { Poland in Transition }\end{array}$ & $4 / 5$ & $12 / 00$ \\
\hline 227 & L. Locher & $\begin{array}{l}\text { Immigration from the Eastern Block and the } \\
\text { former Soviet Union to Israel: Who is coming } \\
\text { when? }\end{array}$ & 1 & $12 / 00$ \\
\hline 228 & $\begin{array}{l}\text { G. Brunello } \\
\text { S. Comi } \\
\text { C. Lucifora }\end{array}$ & $\begin{array}{l}\text { The College Wage Gap in } 10 \text { European } \\
\text { Countries: Evidence from Two Cohorts }\end{array}$ & 5 & $12 / 00$ \\
\hline 229 & $\begin{array}{l}\text { R. Coimbra } \\
\text { T. Lloyd-Braga } \\
\text { L. Modesto }\end{array}$ & $\begin{array}{l}\text { Unions, Increasing Returns and Endogenous } \\
\text { Fluctuations }\end{array}$ & 1 & $12 / 00$ \\
\hline 230 & L. Modesto & $\begin{array}{l}\text { Should I Stay or Should I Go? Educational } \\
\text { Choices and Earnings: An Empirical Study for } \\
\text { Portugal }\end{array}$ & 5 & $12 / 00$ \\
\hline 231 & G. Saint-Paul & The Economics of Human Cloning & 5 & $12 / 00$ \\
\hline 232 & $\begin{array}{l}\text { E. Bardasi } \\
\text { M. Francesconi }\end{array}$ & $\begin{array}{l}\text { The Effect of Non-Standard Employment on } \\
\text { Mental Health in Britain }\end{array}$ & 5 & $12 / 00$ \\
\hline 233 & $\begin{array}{l}\text { C. Dustmann } \\
\text { C. M. Schmidt }\end{array}$ & $\begin{array}{l}\text { The Wage Performance of Immigrant Women: } \\
\text { Full-Time Jobs, Part-Time Jobs, and the Role of } \\
\text { Selection }\end{array}$ & 1 & $12 / 00$ \\
\hline 234 & $\begin{array}{l}\text { R. Rotte } \\
\text { M. Steininger }\end{array}$ & $\begin{array}{l}\text { Sozioökonomische Determinanten extremistischer } \\
\text { Wahlerfolge in Deutschland: Das Beispiel der Eu- } \\
\text { ropawahlen } 1994 \text { und } 1999\end{array}$ & 3 & $12 / 00$ \\
\hline
\end{tabular}


236 R. Hujer

M. Caliendo

237 S. Klasen

I. Woolard

238 R. Euwals

A. Börsch-Supan

A. Eymann

239 F. Andersson

K. A. Konrad

240 W. Koeniger

241 W. Koeniger

242 G. Faggio

J. Konings

243

E. Brainerd

244 S. M. Fuess, Jr. M. Millea

245 F. Andersson

K. A. Konrad

246 E. Plug

W. Vijverberg

247 E. Plug

W. Vijverberg

248 P. M. Picard

E. Toulemonde

249

B. M. S. van Praag

P. Cardoso

250

T. J. Hatton

J. G. Williamson
Evaluation of Active Labour Market Policy:

6

$12 / 00$

Methodological Concepts and Empirical

Estimates

Surviving Unemployment without State Support: 3

$12 / 00$

Unemployment and Household Formation in

South Africa

The Saving Behaviour of Two Person House-

5

$12 / 00$

holds: Evidence from Dutch Panel Data

Human Capital Investment and Globalization in

Extortionary States

5

01/01

Labor and Financial Market Interactions: The

5

$01 / 01$

Case of Labor Income Risk and Car Insurance in the UK 1969-95

Trade, Labor Market Rigidities, and Government- 2 Financed Technological Change

$01 / 01$

Job Creation, Job Destruction and Employment 4

Growth in Transition Countries in the 90's

$01 / 01$

Economic Reform and Mortality in the Former

4

$01 / 01$

Soviet Union: A Study of the Suicide Epidemic in the 1990s

Pay and Productivity in a Corporatist Economy: 5

$01 / 01$

Evidence from Austria

Globalization and Human Capital Formation

5

$01 / 01$

Schooling, Family Background, and Adoption:

5

$01 / 01$

Does Family Income Matter?

Schooling, Family Background, and Adoption:

5

$01 / 01$

Is it Nature or is it Nurture?

The Impact of Labor Markets on Emergence and 2

Persistence of Regional Asymmetries

01/01

"Should I Pay for You or for Myself?"

3

01/01

The Optimal Level and Composition of

Retirement Benefit Systems

Demographic and Economic Pressure on

Emigration out of Africa 
254 H. Gersbach

A. Schniewind

255 H. Gersbach

A. Schniewind

T. Boeri

H. Brücker

257

T. Boeri

258

M. Rosholm

K. Scott

L. Husted

259

A. Ferrer-i-Carbonell

B. M.S. van Praag

260

P. Cahuc

F. Postel-Vinay

261

M. Lindahl

262

M. Lindahl

263

N. Datta Gupta

N. Smith

264

C. Dustmann

265

M. Rosholm

M. Svarer

C. Dustmann

O. Kirchkamp
Learning of General Equilibrium Effects and the Unemployment Trap

3

02/01

Product Market Reforms and Unemployment in 3 Europe

Eastern Enlargement and EU-Labour Markets: 2 Perceptions, Challenges and Opportunities

Transition with Labour Supply

4

02/01

The Times They Are A-Changin':

1

$02 / 01$

Organizational Change and Immigrant

Employment Opportunities in Scandinavia

Poverty in the Russian Federation

4

$02 / 01$

Temporary Jobs, Employment Protection and

$1 / 3$

02/01

Labor Market Performance

Home versus School Learning:

5

02/01

A New Approach to Estimating the Effect of Class Size on Achievement

Summer Learning and the Effect of Schooling:

5

02/01 Evidence from Sweden

Children and Career Interruptions:

5

02/01

The Family Gap in Denmark

Return Migration, Wage Differentials, and the

1

02/01 Optimal Migration Duration

Structurally Dependent Competing Risks

02/01

The Optimal Migration Duration and Activity Choice after Re-migration 
283 M. Hagedorn

A. Kaul

V. Reinthaler

284

H. Rapoport

A. Weiss

285

J. Jerger

C. Pohnke

A. Spermann

286 M. Fertig

C. M. Schmidt

287 P. Guggenberger

A. Kaul

M. Kolmar

288

D. A. Cobb-Clark

289

L. Cameron

D. A. Cobb-Clark

290

D. A. Cobb-Clark

M. D. Connolly

C. Worswick

291

R. T. Riphahn

292

E. Wasmer

293

D. Cobb-Clark

T. F. Crossley

294

Š. Jurajda

295

F. Duffy

P. P. Walsh

296 H. S. Nielsen

M. Rosholm

N. Smith

L. Husted
Welfare Analysis in a Schumpeterian Growth

Gut betreut in den Arbeitsmarkt?

5

04/01

Eine mikroökonometrische Evaluation der

Mannheimer Arbeitsvermittlungsagentur

First- and Second-Generation Migrants in

People Think

Efficiency Properties of Labor Taxation in a

3

$04 / 01$ Spatial Model of Restricted Labor Mobility

$04 / 01$

Getting Ahead: The Determinants of and Payoffs

5 to Internal Promotion for Young U.S. Men and Women

Old-Age Support in Developing Countries:

3

$04 / 01$

Labor Supply, Intergenerational Transfers and Living Arrangements

The Job Search and Education Investments of Immigrant Families

04/01

Cohort Effects in the Educational Attainment of

05/01 Second Generation Immigrants in Germany: An Analysis of Census Data
Between-group Competition in the Labor Market and the Rising Returns to Skill: US and France 1964-2000

Gender, Comparative Advantage and Labor

05/01

Market Activity in Immigrant Families

Estimating the Effect of Unemployment

3

$05 / 01$

Insurance Compensation on the Labor Market

Histories of Displaced Workers

Individual Pay and Outside Options:

4

$05 / 01$

05/01

Evidence from the Polish Labour Force Survey

Intergenerational Transmissions and the School-

1

05/01 
297 J. C. van Ours J. Veenman

298 P. Telhado Pereira P. Silva Martins

299 G. Brunello

C. Lucifora

R. Winter-Ebmer

300 A. Stutzer

R. Lalive

301 J. R. Frick

G. G. Wagner
The Educational Attainment of Second Generation 1 Immigrants in The Netherlands

Returns to Education and Wage Equations

5

06/01

The Wage Expectations of European College

5

06/01 Students

The Role of Social Work Norms in Job Searching

5

$06 / 01$ and Subjective Well-Being

Economic and Social Perspectives of Immigrant

1

06/01
05/01 Children in Germany 